\title{
First Report of a Complete Genome Sequence for a Begomovirus Infecting Jatropha gossypifolia in the
}

\section{Americas.}

R.N. Simmonds-Gordon ${ }^{\mathrm{a}}$, A.M. Collins-Fairclough ${ }^{\mathrm{a}^{*}}$, C.S. Stewart ${ }^{\mathrm{a} * *}$, and M. E. Roye . $^{\mathrm{a}}$

a'Biotechnology Center, 2 St John's Close, University of the West Indies, Mona Campus, Kingston, Jamaica.

*Current address: Faculty of Science and Sport, University of Technology Jamaica, 237 Old Hope Road, Kingston, Jamaica

${ }^{* * *}$ Current address: Institute for Cellular \& Molecular Medicine \& the Department of Immunology, University of Pretoria, 5 Bophelo Road, Pretoria 0031, South Africa

Corresponding author: Marcia Roye. 1-876-977-1828. Fax 1-876-977-3331. marcia.roye@uwimona.edu.jm

\begin{abstract}
Jatropha gossypifolia is a weed that is commonly found with yellow mosaic symptoms growing along the roadside and in close proximity to cultivated crops in many farming communities in Jamaica. For the first time, the complete genome sequence of a new begomovirus designated Jatropha mosaic virus-[Jamaica:Spanish Town:2004] (JMV[JM:ST:04]) was determined from field-infected J. gossypifolia in the Western Hemisphere. DNA-A nucleotide sequence comparisons showed closest identity (84\%) to two tobacco-infecting viruses from Cuba, (Tobacco mottle leaf curl virus-[Cuba:Sancti Spiritus:03] (TbMoLCV-[CU:SS:03]), Tobacco leaf curl Cuba virus[Cuba:Taguasco:2005] (TbLCuCUV-[CU:Tag:05]); and two weed-infecting viruses from Cuba and Jamaica, Rhynchosia rugose golden mosaic virus-[Cuba:Camaguey:171:2009] (RhRGMV- [CU:Cam:171:09]) and Wissadula golden mosaic St. Thomas virus-[Jamaica:Albion:2005] (WGMSTV-[JM:Alb:05]). Phylogenetic analysis revealed that JMV-[JM:ST:04] was most closely related to tobacco and tomato viruses from Cuba and, WGMSTV-

[JM:Alb:05], a common malvaceous weed-infecting virus from Eastern Jamaica, and is distinct from begomoviruses infecting Jatropha species in India and Nigeria.
\end{abstract}

Keywords: begomovirus, Jatropha gossypifolia, Jamaica

Jatropha gossypifolia is a wild or uncultivated shrub that grows ubiquitously in Jamaica, oftentimes displaying yellow mosaic symptoms typical of begomovirus infection (Fig 1). J. gossypifolia belongs to the Euphorbiaceae 

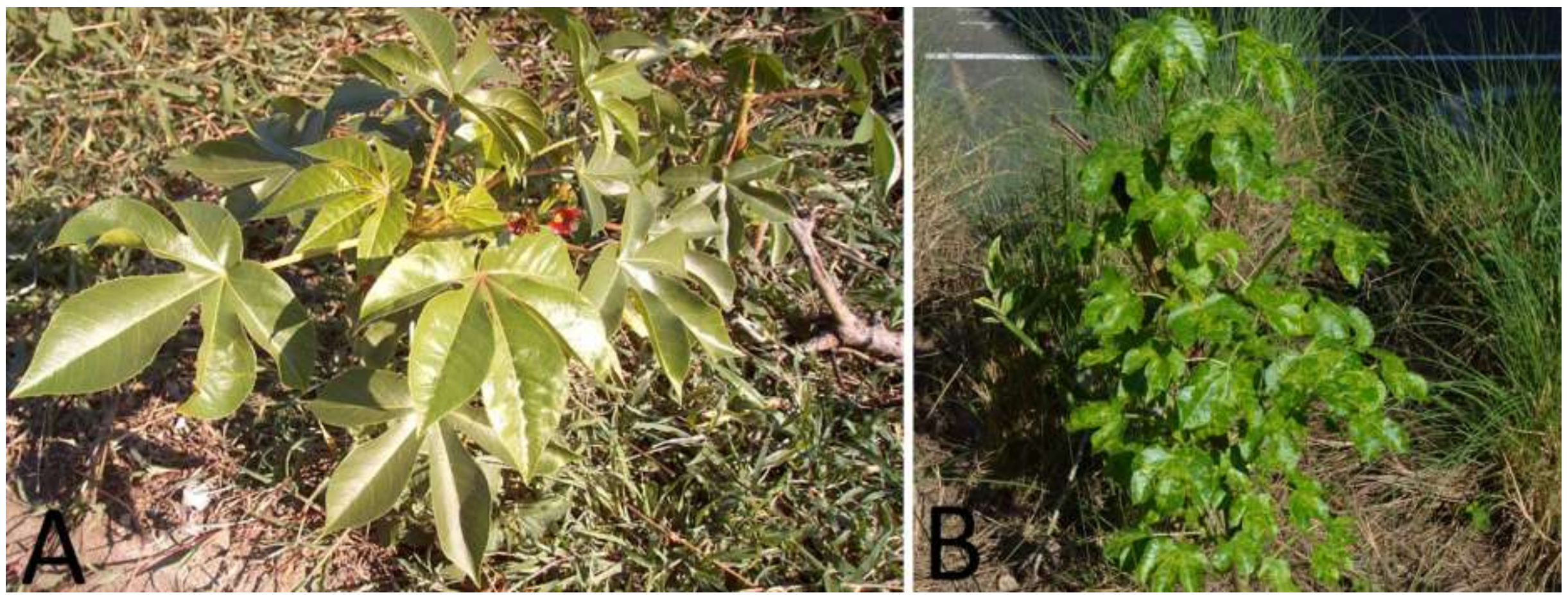

Fig 1 (A) Healthy and (B) field infected Jatropha gossypifolia with yellow mosaic symptoms. 
family which includes important crop species such as Ricinus communis (castor bean), Hevea brasiliensis (rubber tree) and, Manihot esculenta Crantz (cassava) which is widely cultivated in many African countries and around the world. J. gossypifolia can be found growing wild in Africa, North America, India and the Caribbean [16]. It contains active antimicrobial components [11] and has many medicinal uses including the treatment of dysentery [16, 18] even though it is known to be potentially toxic when ingested [4]. Jatropha species have been harnessed for their seed oil that is used in the making of glue, dye and soap but more importantly as feedstock for biodiesel production. The seed cake, which is the byproduct of the seed oil extraction process, is high in nitrogen and phosphorus, thus making it ideal as a natural fertilizer [10].

J. gossypifolia susceptibility to begomovirus infection was reported in 1930s in Puerto Rico [3], in 1951, symptoms were observed in Jamaica, Martinique and Guadeloupe [2]. Viruses associated with Jatropha mosaic disease have also been reported in Cuba [8], India [15, 16], Kenya [12], Singapore [6] and Nigeria [7]. J. gossypifolia has also shown susceptibility to begomoviruses from another euphorbiaceous species, Croton sp. [15].

The Geminiviridae family of viruses cause significant yield loss in crops. Members of the Begomovirus genus are whitefly-transmitted viruses that infect dicotyledons [19]. Wild plants can serve as alternate hosts and reservoirs for some crop infecting geminiviruses $[1,9,14]$. In Jamaica, begomoviruses have been characterized from vegetable crops such as tomato, pepper and cabbage and numerous uncultivated plants with yellow mosaic and leaf curl symptoms [17]. Partial DNA-A and DNA-B genomic sequences have been reported for a virus isolated from $J$. gossypifolia in Jamaica, tentatively named Jatropha mosaic virus (JMV, [13]). Complete DNA-A sequences are a minimum for establishing virus species [5]. Complete genome sequences also provide thorough insights into the relationship between the circulating begomoviruses and are useful for understanding virus evolution and emergence of new outbreaks. Here we report the first complete genome sequences of a bipartite begomovirus that infects Jatropha spp. in the Western Hemisphere.

Total DNA was extracted from symptomatic leaves of $J$. gossypifolia collected from Spanish Town, Jamaica in 2004. The previously reported nucleotide sequences for JMV (accession numbers AF324410, AF324410) were used to design overlapping primers to amplify complete DNA components. The DNA-A primers pJAC1v2123 (5'TGGAATTCTCCCCATTCCAGT GTATCTCC) and pJAC1c2132 GAGAATTCCAGATCGACGGACGAAGTGC) overlapped at an EcoRI site, whilst the DNA-B primers 
pJBV1v556 (5'- CATGCATGAGAATCAGTATGGGCCTGA) and pJBV1c563 (5'CATGCATGCGTTGACATGACATCTTGG) overlapped at an NsiI site, and amplified the expected $2.7 \mathrm{~kb}$ fragment. Amplicons were cloned using the TOPO TA cloning kit (Invitrogen) and sequenced by Macrogen, South Korea. The Clustal V algorithm in MegAlign (DNAStar, Lasergene 7.0) was used to construct the multiple alignments, phylogenetic trees and compute sequence distances. Nucleotide sequences were obtained for three DNA-A clones (JCA1, 2 and 3; KF723258, KF723259, KF723260) which were 2610 nts and were between 98.9100\% identical, as well as two DNA-B clone JCB1 and 2, (KF723261, KF723262) which were 2588 nts and were $100 \%$ identical. The JCA clones possessed the begomovirus coat protein, replication initiator protein, transcriptional activator protein and replication enhancer protein genes in their canonical positions. The nuclear shuttle protein and movement protein genes were observed in the JCB clones. A comparison of the JCA and JCB clones revealed a 165 bp common region (CR) sequence of $99.4-100 \%$ identity. The CR contained the invariant geminivirus nonanucleotide (TAATATTAC), the TATA box and a virus specific iterated sequence GGGGGAAC, which occurred three times in the CR, twice as direct adjacent repeats and once as an inverted repeat (GTTCCCCC). The CR identity and architecture suggest that these sequences represent DNA-A and DNA-B isolates that could form an infectious begomovirus unit.

The sequence of the JCA and JCB clones were used in a BLASTn search of the NCBI database. Sequences sharing at least $85 \%$ similarity to JCA with a minimum of $90 \%$ sequence coverage were selected based on the BLAST local alignment for inclusion in a DNA-A multiple sequence alignment that also contained all reported begomoviruses that infect Jatropha spp., begomoviruses from Jamaica and representatives from the Western Hemisphere begomovirus clades. The JCA clones showed highest sequence identity (84\%) to four begomoviruses from the Caribbean region, Rhynchosia rugose golden mosaic virus-[Cuba:Camaguey:171:2009] (RhRGMV[CU:Cam:171:09]), Tobacco mottle leaf curl virus-[Cuba:Sancti Spiritus:2003] (TbMoLCV-[CU:SS:03]), Tobacco leaf curl Cuba virus-[Cuba:Taguasco:2005] (TbLCuCUV-[CU:Tag:05]) and Wissadula golden mosaic St. Thomas virus-[Jamaica:Albion:2005] (WGMSTV-[JM:Alb:05]). In accordance with the 89\% sequence similarity rule for demarcating begomovirus species (Fauquet et al 2008), the JCA sequences represent the complete DNA-A of a distinct begomovirus species. The JCB sequences shared highest nucleotide identity (70\%) to WGMSTV[JM:Alb:05], a weed-infecting virus from Jamaica. 


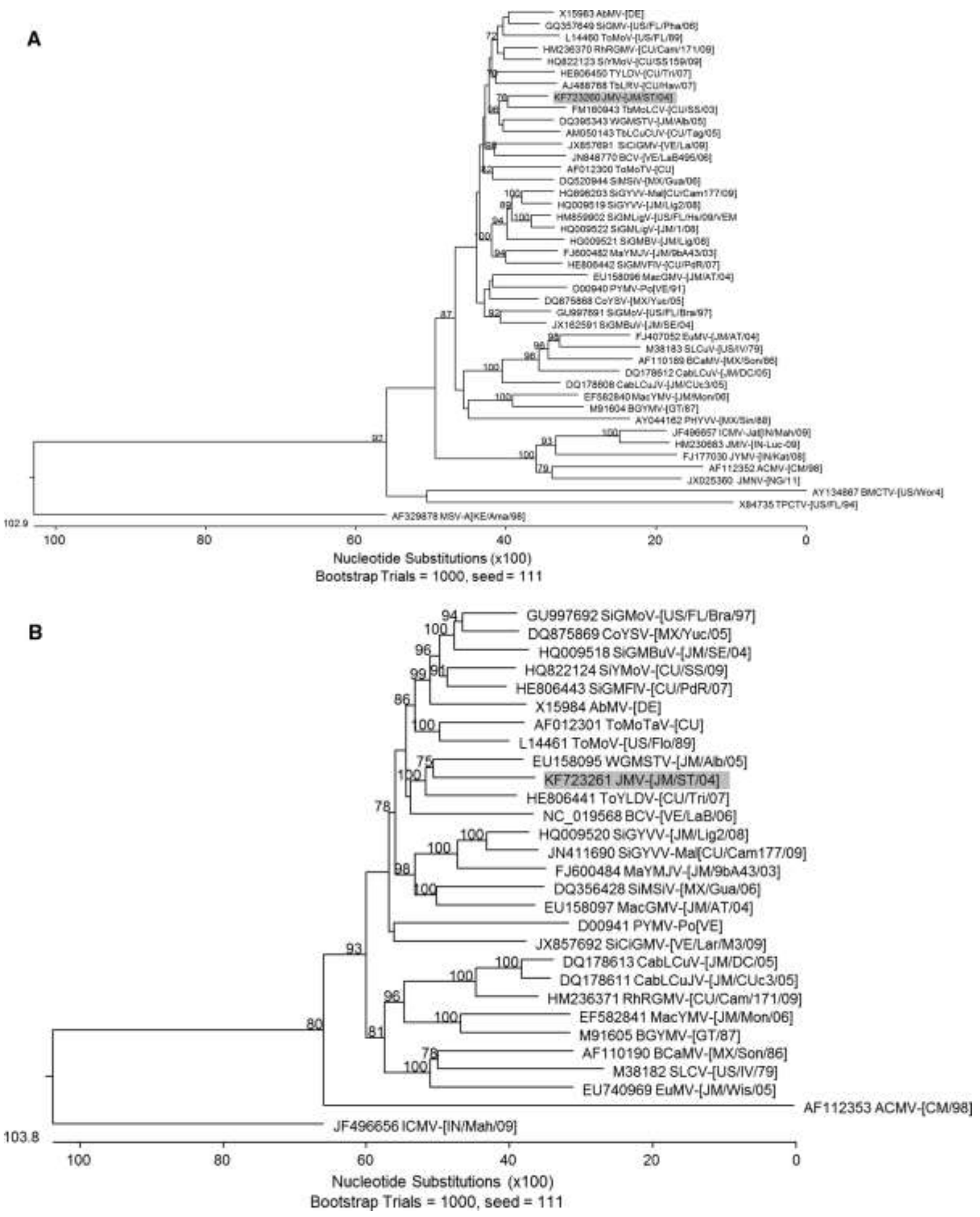

Fig 2: Phylogeny of JMV-[JM:ST:04] based on (A) DNA-A and (B) DNA-B. 
The previously reported partial JMV DNA-A isolated from J. gossypifolia in Jamaica was 93\% identical to nucleotides 1772-547 of sequence the JCA clones, whilst the JCB clones shared 85\% identity to partial JMV DNAB clones. The JCA clones are likely the complete DNA-A isolates of JMV species based on DNA-A similarity and association with the yellow mosaic of J. gossypifolia in Jamaica. The JCA and JCB clones therefore denote the first complete DNA-A and DNA-B for a begomovirus infecting J. gossypifolia in the Americas and are designated isolates 1-3 of Jatropha mosaic virus-[Jamaica:Spanish Town:2004] (JMV-[JM:ST:04]).

Phylogenies inferred from the multiple alignments show the DNA-A of JMV-[JM:ST:04] clustering with TbLCuCUV-[CU:Tag:05], WGMSTV-[JM:Alb:05] and TbMoLCV-[CU:SS:03], whilst the DNA-B clustered with WGMSTV-[JM:Alb:05] and Tomato yellow distortion leaf virus-[Cuba:Trinidad:2007] (ToYDLV-[CU:Tri:07]) (Fig 2). Both phylogenies were well supported with bootstrap values over 95\% and show that JMV-[JM:ST:04] was more closely related to begomoviruses in the Americas than to monopartite begomoviruses infecting Jatropha spp. in the Eastern Hemisphere [7, 16] which were 52-54\% identical to JMV-[JM:ST:04]. A close evolutionary relationship between JMV-[JM:ST:04] and begomoviruses infecting tobacco and tomato in Cuba has been observed.

\section{Acknowledgements}

Funding was provided by the School of Graduate Studies and Research and the Principal's New Initiative Fund, University of the West Indies, Mona.

\section{References}

1. Ascencio-Ibáñez JT, Argüello-Astorga GR, Méndez-Lozano J, Rivera-Bustamante R F (2002) First report of Rhynchosia golden mosaic virus (RhGMV) infecting tobacco in Chiapas, Mexico. Plant Dis $88: 692$

2. Bird J (1957) A whitefly transmitted mosaic of Jatropha gossypifolia. Tech paper 22. Agri Exp Station, University of Puerto Rico

3. Cook MT (1931) New virus diseases of plants in Puerto Rico. J Depart Agri Puerto Rico 15: 193-195

4. Devappa RK, Makkar HP, Becker K (2010) Jatropha toxicity - a review. J Toxicol Environ Health B Crit Rev 13:476-207

5. Fauquet CM, Briddon RW, Brown JK, Moriones E, Stanley J, Zerbini M, Zhou X (2008) Geminivirus strain demarcation and nomenclature. Arch Virol 153:783-821

6. Gão S, Qu J, Chua N, Ye J, (2010) A new strain of Indian cassava mosaic virus causes a mosaic disease in the biodiesel crop Jatropha curcas. Arch Virol 155:607-612

7. Kashina BD, Alegbejo MD, Banwo OO, Nielsen SL, Nicolaisen M (2013) Molecular identification of a new begomovirus associated with mosaic disease of Jatropha curcas L. in Nigeria. Arch Virol 158:511-514

8. Martínez Y (2008) Emergence of begomoviruses in Cuba. Revista de Protección Vegetal 23:11-15 
9. Méndez-Lozano JL, Perea-Araujo L, Ruelas-Ayala RD, Leyva-López NE (2006) A begomovirus isolated from chlorotic and stunted soybean plants in Mexico is a new strain of Rhynchosia golden mosaic virus. Plant Dis 90:972

10. Misra M, Misra AN (2010) Jatropha: The biodiesel plant biology, tissue culture and genetic transformation- a review. Int J Pure Appl Sci Technol 1:11-24

11. Ogundare AO (2007) Antimicrobial effect of Tithonia diversifolia and Jatropha gossypifolia leaf extracts. Trends in Appl Sci Res 2:145-150

12. Ramkat RC, Calari A, Maghuly F, Laimer M (2011) Biotechnological approaches to determine the impact of viruses in the energy crop plant Jatropha curcas Virol J 8:386-395

13. Roye ME, Collins, AM, Maxwell DP (2006) First report of a begomovirus associated with the common weed Jatropha gossypifolia in Jamaica. Plant Path 55:286

14. Sánchez-Campos S, Navas-Castillo J, Monci F, Díaz JA, Moriones E 2000 Mercurialis ambigua and Solanum luteum: Two newly discovered natural hosts of Tomato yellow leaf curl geminiviruses. Euro J of Plant Path 106:391-394

15. Snehi SK, Khan MS, Raj SK, Prasad V (2011a) Complete nucleotide sequence of Croton yellow vein mosaic virus and DNA-b associated with yellow vein mosaic disease of Jatropha gossypifolia in India. Virus Genes 43:93-101

16. Snehi SK, Raj SK, Khan MS, Prasad V (2011b) Molecular identification of a new begomovirus associated with yellow mosaic disease of Jatropha gossypifolia in India. Arch Virol 156 2303-2307

17. Stewart CS (2010) The molecular characterization of begomoviruses infecting Sida spp. in Jamaica. $\mathrm{PhD}$ thesis, University of the West Indies, Mona Jamaica

18. Uddin MZ, Hassan A, Sultana M (2006) Ethnobotanical survey of medicinal plants in Phulbari Upazila of Dinajpur district, Bangladesh. Bangladesh J Plant Taxon 13: 63-68

19. Varma A, Malathi VG (2003) Emerging geminivirus problems: A serious threat to crop production. Ann App Biol 142:145-164 